\title{
Review of Methodologies for Assessing Sustainable Diets and Potential for Development of Harmonised Indicators
}

\author{
Paul Eze Eme ${ }^{1, *}$, Jeroen Douwes ${ }^{2}$, Nicholas Kim ${ }^{1}$, Sunia Foliaki ${ }^{2}$ and Barbara Burlingame ${ }^{1}$ \\ 1 School of Health Sciences, College of Health Science, Massey University, Palmerston North 4442, \\ New Zealand; n.kim@massey.ac.nz (N.K.); b.burlingame@massey.ac.nz (B.B.) \\ 2 Centre of Public Health Research, Massey University, Wellington 6140, New Zealand; \\ j.douwes@massey.ac.nz (J.D.); s.foliaki@massey.ac.nz (S.F.) \\ * Correspondence: p.eme@massey.ac.nz; Tel.: +642-102-990-048
}

Received: 19 February 2019; Accepted: 25 March 2019; Published: 2 April 2019

\begin{abstract}
The underlying values and priorities that drive policy responses depend largely on the constructs that researchers and decision makers select to measure and the metrics used. Despite much recent attention being given to sustainable diets and food systems and to the importance of clearly measuring sustainability to meet targets, to achieve goals, and to appraise dietary and environmental policies, it is not commonly agreed how the different indicators of sustainable diets are assessed. The evidence base for assessment of these indicators are frequently weak, fragmented, and arbitrary. The aim of this paper was to compare a range of published methods and indicators for assessing sustainable diets and food systems in order to harmonise them. Keyword and reference searches were performed in PubMed, Scopus, CAB Abstracts, and Web of Knowledge. Fifty-two studies (21 proposed methods and 31 used methods) that combined environment, nutrition and health, and socioeconomic aspects of sustainable diets were reviewed. The majority (over 90\%) of the studies focused on high-income countries. Twenty-eight studies assessed the environmental effects of different dietary practices, eight of the studies examined the nutrition and health indicators used for assessing sustainable food systems, and seven studies assessed the social and economic costs of diets. A classification of the elements was developed, and common elements are proposed for standardizing. These elements were categorized into nutrition and health indicators, environment indicators, and socioeconomic indicators. Standardized or harmonized indicators can be used for consistency and applicability purposes and to support, implement, and monitor relevant policies.
\end{abstract}

Keywords: sustainable diets; food systems; indicators; health; economic; nutrition

\section{Introduction}

The Food Agriculture Organization (FAO), World Health Organization (WHO), and United Nation University (UNU) [1] define diet as the set of food, beverages, and nutrients that are consumed by an individual or by a community of individuals during a certain period. A number of environmental, health-related, and socioeconomic factors can influence diets. The consideration of the interrelationships between these factors, particularly in the context of environmental resource limits, led to the concept of sustainable diets. According to FAO [2], sustainable diets are defined as those diets with low environmental impacts, which contribute to food and nutrition security and to a healthy life for present and future generations. Sustainable diets are protective and respectful of biodiversity and ecosystems, culturally acceptable, accessible, economically fair and affordable, nutritionally adequate, safe, and healthy while optimizing natural and human resources. 
"All food systems are sustainable." is the central policy objective of the UN's Zero Hunger Challenge and an explicit feature of Sustainable Development Goal 2 (SDG 2) which seeks to "end hunger, achieve food security and improved nutrition, and promote sustainable agriculture." Although they may appear straightforward, food systems and dietary patterns are in fact determined by a complex interplay of human, economic, social, environmental, and political factors. They can be difficult to define and characterise from any one perspective in terms of sustainability and may require multiple indicators for effective measurements.

In keeping with this, food systems have been defined and assessed in the literature from a range of perspectives [3,4]. At the same time, it is appreciated that a complete and encompassing definition should reflect the sum total of processes that link agricultural production to consumption, including food losses and waste, as well as the positive and negative impacts of these activities and processes on human and environmental health and wellbeing. The High Level Panel of Experts for the Committee on World Food Security states: A food system gathers all the elements (environment, people, inputs, processes, infrastructures, institutions, etc.); activities that relate to the production, processing, distribution, preparations, and consumption of food; and the outputs of these activities, including socioeconomic and environmental outcomes [5].

Globally, food security is threatened by the degradation of terrestrial, freshwater, and marine ecosystems and species used for medicine and food which are increasingly being neglected, underutilised, and ultimately lost. For example, according to FAO [6], approximately 200 million people are employed by the worlds' fisheries, which contribute about 16 percent of the total protein eaten by the world. Nonetheless, approximately 80 percent of the world marine fish stocks, for which appraisal information is available, are overburdened, weakened, or recuperating from depletion. Bell and Taylor [7] reported that the Pacific Island Countries were facing many challenges to food security-accessibility, availability, and the utilization of nutritious foods. The authors outlined the causes of the challenges: fast population growth and urbanization; limited opportunities to acquire income; high levels of imported and processed foods high in salt, sugars, and fats; and the inability of communities to engage in small-scale agriculture production (SDG 2) due to a deficit of cultivable land.

Diets as drivers of sustainable food systems have been discussed across many inter-sectoral bodies and interdisciplinary perspectives, resulting in mounting information and analytical research and a range of methodologies [8]. Despite being agreed upon, methodologies for quantifying sustainable diets show considerable variation with each other and may or may not be generally applicable, and resolving this variation is the rationale of the study. The harmonization of these indicators will contribute to the global monitoring of SDGs in addition to reporting on targets related to food systems and diets. This will ensure that the interconnected issues represented by different assessment targets are bridged as well as that the total amount of indicators needed for creating an extensive monitoring indicators framework for assessing sustainable food system is reduced. For example, the harmonization of gender indicators in Kyrgzstan strengthened the gender monitoring of the Millennium Development Goals (MDGs) in their different regions [9]. Some of the indicators have been field-tested more than others. In our view, there are two interrelated needs. Firstly, and to the extent possible, it would be desirable for the various methodologies to be harmonised. Secondly, methodological approaches for characterising sustainable diets should be field-tested in different regions to determine their specificity, appropriateness, and applicability. The need to characterise pressures that drive the divergence between current dietary patterns and sustainable diets is particularly urgent for populations with extreme and immediate vulnerabilities such as Small Island Developing States (SIDS). The main challenge in this area is that there are several diverse ways to aggregate different methods and indices for the purpose of harmonisation. In this paper, the aim of the study was to compare the different methodological frameworks proposed for assessing sustainable diets and food systems and to harmonize the proposed indicators. 


\section{Materials and Methods}

A literature search was performed in PubMed, Scopus, CAB Abstracts, and Web of Knowledge bibliographies between March 2017 and November 2018 using the search terms "sustainable food system" or "sustainable diet" and "assessment", "health", "environment", "nutrition", "social", or "economics". The search window was 1995-2018 with restriction to items published in English. Figure 1 shows the detailed process of the manuscripts included. Both peer-reviewed works and appropriate publications from the grey literature (such as conference proceedings and technical reports) were included, as long as they met all the following inclusion criteria: the quantification of environmental indicators linked to dietary intakes as greenhouse gas emissions, land use, or water use at a population level; the collection of dietary information to elucidate baseline diets at the national, household, or individual level; the estimation of the healthy aspects of sustainable diets; and the measurement of socioeconomic variables. Articles with no clearly identifiable indicators for assessing sustainable food systems, as well as review articles, were excluded. Potential papers meeting the inclusion criteria were accessed, and the details were extracted on the following variables: country of the study, main objective(s) of the paper, main findings, and main indicators identified. Only the full texts were included in the final analyses.

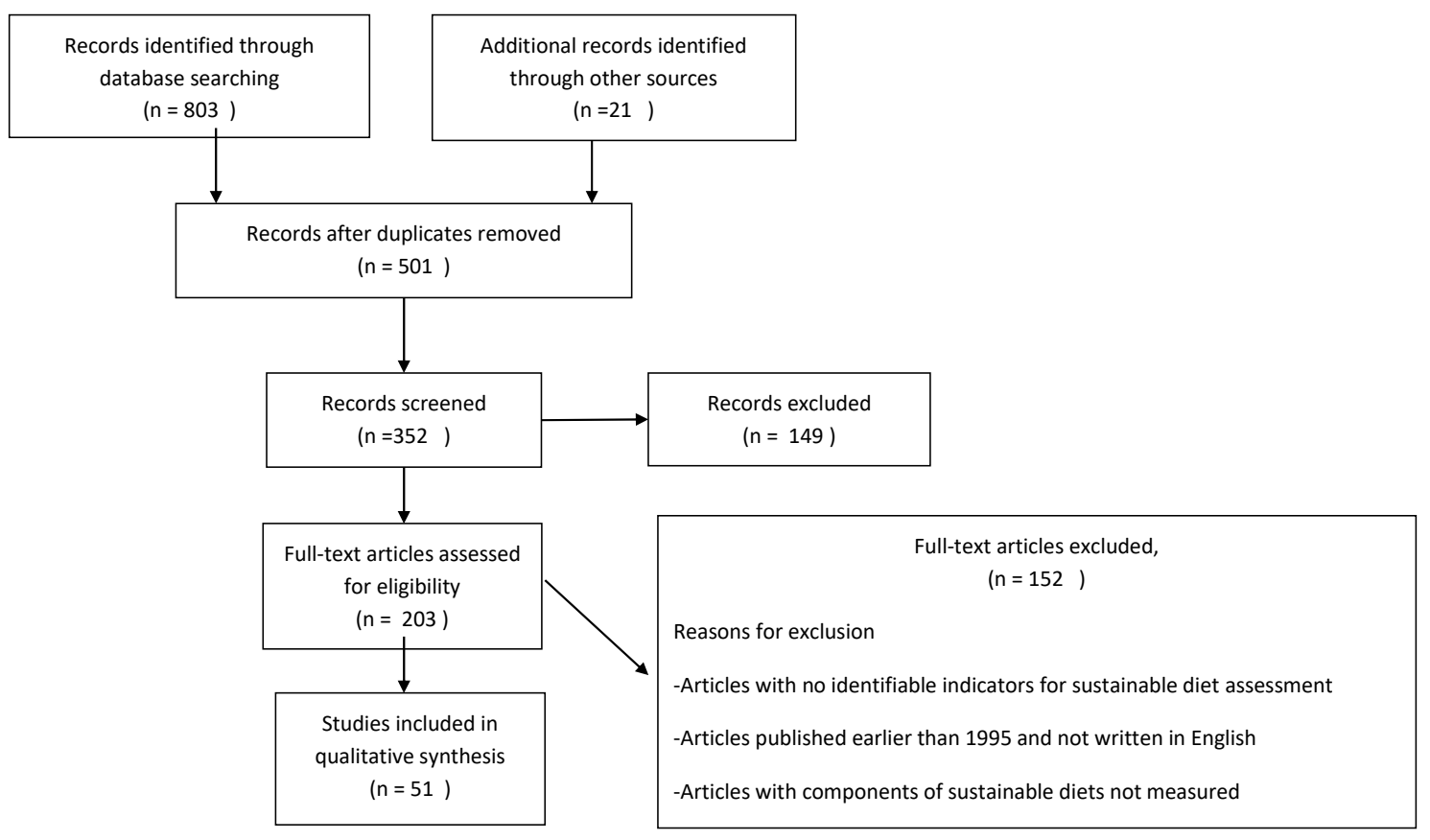

Figure 1. A flow chart of how the articles were selected and included in the review.

The harmonisation of the indicators was undertaken using the "interoperability cube" approach introduced by Mulder [10], specifically designed to explore and enable the harmonisation of methods and tools used in "living labs" research, including among the European Network of Living Labs (ENoLL). The cube builds on the idea that the main focus is on synergies and the parts that living labs wish to exchange with one another and with other forms for the harmonization of methods and tools. The cube identifies these exchange prospects and expressly defines these parts from structural, technical and discourse views. The more elements that match, the better the harmonisation. Up to five clusters can be used in the harmonization process. In this research, three of the clusters were used: user involvement, innovation outcomes, and methods and framework because they were deemed to be of the most relevance or applicability to the topic under investigation.

The "user involvement" indicators were designed according to an iterative approach [11]. The questions asked about the indicators included: "How to organize user involvement?", "Who are the right users?" and "What is the efficacy level?" Users are important to define context-aware services, 
e.g., cultural differences. User context includes experience in the use of the indicator for data collection, the ability to apply and interpret the data using acceptable standard measures, and developing a strong interest in translating the set data into beneficial policies. Under the "innovation outcomes" cluster, the factors considered were the degree of flexibility of the indicators, user knowledge ability and the frequency of usage among the international agencies in measuring sustainable food systems. For "availability of the framework and methods", the existence of reference standard methods and cultural preferences were considered. The indicators were classified under three categories: environment, nutrition and health, and socioeconomic.

\section{Results and Discussion}

This review covered 51 empirical studies of which only eight were published more than 10 years ago. The reviewed articles were classified under the categories of environment, nutrition and health, and socioeconomic. An inventory of the environmental indicators used for assessing sustainable diets across the different studies is provided in Table 1. A tabulation of the nutrition and health indicators is provided in Table 2, and the compiled socioeconomic indicators are shown in Table 3. A short list of harmonised indicators across these three categories is given in Table 4.

\subsection{Potential for Geographic Bias}

The majority (over 90\%) of studies focused on high-income countries in western Europe and the USA (Figure 2). In spite of the fact that these high-income countries have substantially contributed to greenhouse gas emissions (GHGEs) related to food systems and agriculture, the detrimental effects of climate change and resource degradation shown in several of the measured segments of sustainability are likely to be felt most heavily in the low- and middle-income countries (LMICs) [12]. As evidence obtained from these high-income countries are being used by the governments of the LMICs to establish dietary guidelines, the problems and needs of these countries may not be effectively addressed.

\subsection{Environmental Indicators}

Thirty-two studies assessed the environmental effects of different dietary practices. These studies analysed the varying attributes of diets affecting land use, water, energy, planetary boundaries and many ecosystem services that were based on all the processes along food chain. Some of the environmental data in the studies showed decreased environmental footprints from the replacement of animal-based foods with plant-based foods, while others showed that plants had a higher footprint [13-16]. Whereas most studies showed lower environmental impacts from plant-based diets, a few studies showed a higher water footprint, and GHG emissions were observed from the replacement of calories from meat-reduction scenarios with increased plant-based foods [17,18]. Studies have shown that the formulation of substitute dietary patterns was also a factor in instances of higher environmental effects. For example, in Vieux et al. [19], meat reduction supplemented isocalorically by fruits and vegetables reflected a rise in emissions, while a secondary scenario of a replacement with mixed foods saw a net decrease.

In the use of an estimated Life Cycle Assessment (LCA) of diets, GHGE and the water footprint were the most common indicators measured ( $n=26$ studies; $41.1 \%$ of sample). This is consistent with previous reviews in related areas $[20,21]$ which also identified LCA indicators as the most common assessment of dietary patterns. In their systematic review on the estimation of the potential to reduce GHGE and land use demands by varying the composition of the diet, up to $50 \%$ of the reviewed papers used GHGE as the indicator for measuring the environmental effect of diets. Environmental management system performance ( $\mathrm{n}=11$ studies; $18.7 \%$ of sample) and land use, especially total per capita land requirement ( $\mathrm{n}=6$ studies; $10 \%$ of the sample), were the second and third most frequently mentioned environmental indicators. Energy use, use of planetary boundary framework metrics and water use linked with the production and processing of foods were also commonly cited but in $<5 \%$ of the studies. 


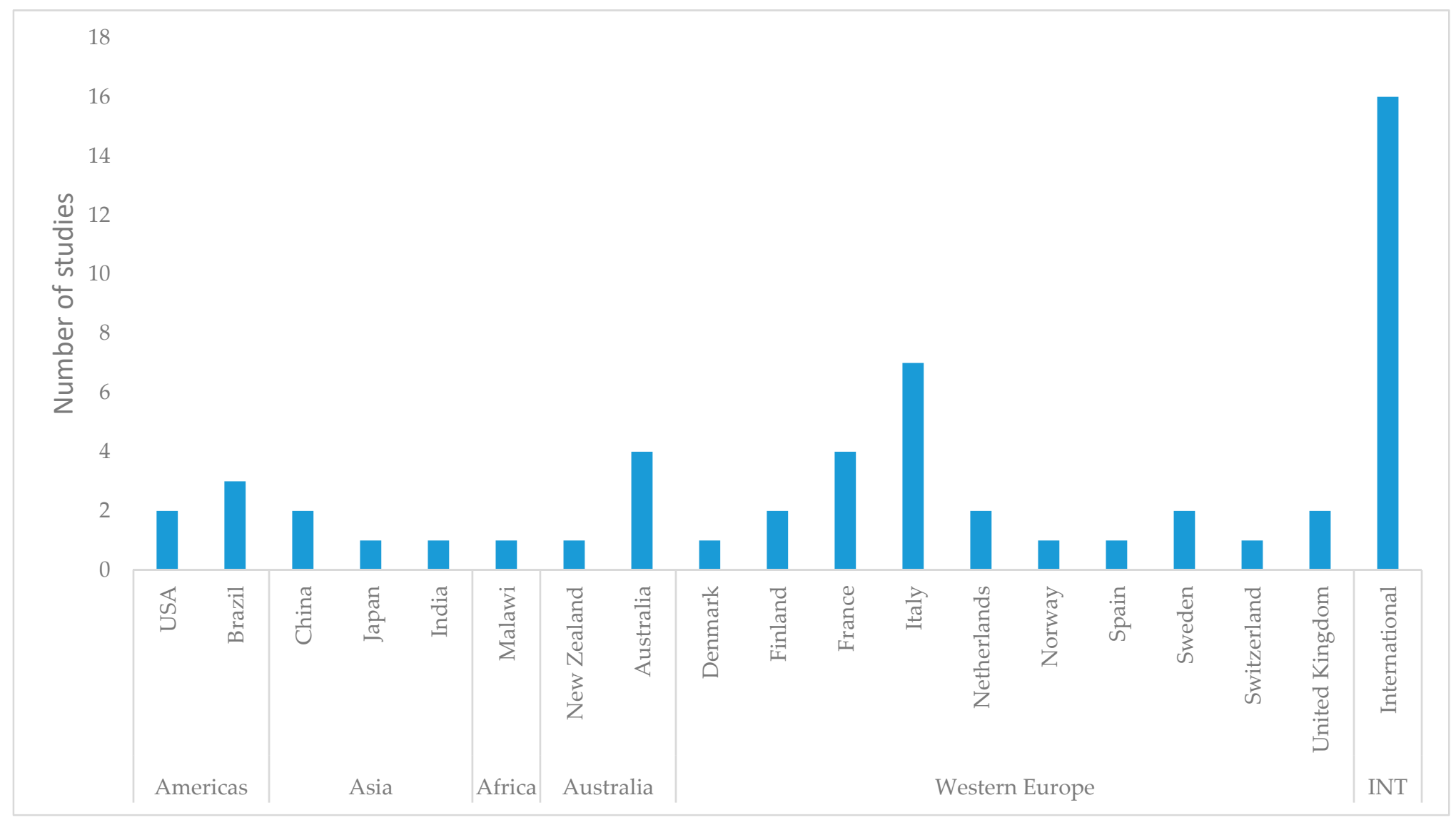

Figure 2. The distribution of the number of studies by countries and continents. 


\subsection{Nutrition and Health Indicators}

Twelve of the studies examined the nutrition and health indicators used for assessing sustainable food systems. Dietary intake assessments which include dietary diversity and dietary quality were the most common nutrition indicators assessed ( $\mathrm{n}=9$ studies; $56.3 \%$ of sample). The Dietary Diversity Index, which is defined as the ratio of those obtaining a diverse diet to the overall population, is known as a promising indicator of dietary quality in the field of development economics [22] and, therefore, a relevant tool that could be used in other categories for measuring sustainable food systems. The other common indicators included the outcomes of focus group discussion, diet-related morbidity and mortality statistics, the rate consumption of local/regional foods, and the seasonality and rate of eco-friendly foods.

\subsection{Socioeconomic and Other Indicators}

The remaining eight studies assessed the socioeconomic indicators of diets at varying micro and macro levels. They focused on the value effects of purchasing power, the socioeconomic and lifestyle determinants, and the consumers' preferences. The Price Index, income, wealth and equity indices were the most common socioeconomic indicators/indices used for measuring sustainable food systems. Most of these indicators identified could be used to measure the poverty index of a population. Research has shown that a sustainable diet is impacted not only by poverty but also by inequality [23]. Although, not part of the review because it is a trade-industry paper, the Sustainability Consortium has used a wide multi-stakeholder process to carry out a comprehensive "hot spot" analysis within the food supply chain and has identified potential societal indicators as affecters of sustainable food systems [24]. Other indicators include the agricultural production on sustainable food systems and the production area index.

\subsection{Development of the Harmonised Indicators}

Existing assessment indicators for measuring sustainable food systems in different categories are shown in Tables 1-3. These indicators were categorized by the general process concepts. The development of the harmonized model represents the overall maturation of reasoning behind the internationally recognized assessment models. The predominant idea is that the harmonized indicators were to be based on user involvement, innovation outcomes and the availability of reference standards. The structures of the harmonized indicators regarded as similar have been unified. For example, under environmental indicators, LCA was the main methodological tool for assessing the environmental impact of a product in its life cycle. Carbon footprint, water footprint and ecological footprint are indicators for measuring LCA in any food system and were all selected. Environment management performance indicators and land use were selected because of its frequent use in measuring the environmental impact of food system. Elements missing from one indicator but could be found in the other indicators have been added to the first one. For example, under the socioeconomic indicators in the harmonized tool, income, wealth and equity indicators can be used to obtain all the other indicators in the same category. Fruit and vegetable biodiversity and the nutrient/non nutrient composition of foods were new indicators added in the harmonized indicators because of the lack of published data in their usage in measuring sustainable food systems. The role of these two new indicators in measuring sustainable diets has not been extensively discussed. Azzini et al. [25] emphasized the importance of nutritional quality as an element in dealing with local food sustainability. Barre et al. [26] proposed the need for integrating nutrient bioavailability when identifying sustainable diets.

An assessment and comparison of the sustainability of food production and dietary patterns in different countries could be facilitated by the widespread use of either a single harmonised system as developed in this paper or a standardised set of core indicators. 
Table 1. The environmental indicators used for assessing a sustainable diet.

\begin{tabular}{|c|c|c|c|c|}
\hline Reference & Country & Objective of the Paper & Main Findings & Main Indicators/Index Identified \\
\hline Wratten et al. [27] & New Zealand & $\begin{array}{l}\text { Measuring of sustainability in } \\
\text { agricultural systems }\end{array}$ & $\begin{array}{l}\text { The "Selwyn Stewardship Monitoring Scheme" in } \\
\text { New Zealand showed that the arable farm was the } \\
\text { most efficient with meat and that farms that deals } \\
\text { with dairy were considerably less efficient. }\end{array}$ & $\begin{array}{l}\text { - Selwyn Stewardship } \\
\text { Monitoring Scheme }\end{array}$ \\
\hline Carlsson-Kanyama. [12] & Sweden & $\begin{array}{l}\text { Determine the outcome of greenhouse gas } \\
\text { emissions (GHGEs) on rice, dry pea, carrot, } \\
\text { potato, tomato and pork production }\end{array}$ & $\begin{array}{l}\text { Animal rearing and crop management practices were } \\
\text { more relevant to environmental outcomes than other } \\
\text { areas of the food supply chain. }\end{array}$ & $\begin{array}{l}\text { - } \quad \text { Life Cycle Assessment (LCA): } \\
\text { Energy use }\end{array}$ \\
\hline Jungbluth et al. [28] & Switzerland & $\begin{array}{l}\text { Assess obstacles and choices for the } \\
\text { purchase of foods that are } \\
\text { environmentally friendly }\end{array}$ & $\begin{array}{l}\text { The largest impact on lowering diet-related GHGEs } \\
\text { was not buying air-transported products and meat } \\
\text { consumption reduction. }\end{array}$ & LCA \\
\hline White [29] & International & $\begin{array}{l}\text { Examines how the role of changes in diet } \\
\text { across populations leads to inequality in the } \\
\text { delivery of environmental impacts }\end{array}$ & $\begin{array}{l}\text { An inequality in dietary energy distribution is linked } \\
\text { with an inequality in the use of land to a lesser extent } \\
\text { than meat-intensive diets. }\end{array}$ & $\begin{array}{ll}- & \text { Ecological footprint } \\
- & \text { Gini coefficient } \\
- & \text { Depth of the food deficit } \\
- & \text { Dietary energy in the food supply } \\
- & \text { Per capita food supply variability }\end{array}$ \\
\hline $\begin{array}{l}\text { Gerbens-Leenes, Moll and } \\
\text { SchootUiterkamp [30] }\end{array}$ & International & $\begin{array}{l}\text { The use of environmental indicators for the } \\
\text { production and sustainability of } \\
\text { food systems }\end{array}$ & $\begin{array}{l}\text { Three performance indicators were identified: energy, } \\
\text { the total land and water requirement per kilogram of } \\
\text { available food to be used by individuals, business } \\
\text { sectors and companies. }\end{array}$ & $\begin{array}{ll}- & \text { Depletion of resources } \\
- & \text { Quality of urban environment } \\
- & \text { Waste treatment } \\
- & \text { Environment management } \\
& \text { system performance }\end{array}$ \\
\hline Moldan et al. [31] & International & $\begin{array}{l}\text { To identify and describe composite } \\
\text { indicators of environmental sustainability }\end{array}$ & $\begin{array}{l}\text { A number of composite indicators were identified and } \\
\text { described. which include the Environmental } \\
\text { Sustainability Index (ESI), Dashboard of Sustainability } \\
\text { (DS) and Wellbeing/Stress Index (WI) }\end{array}$ & $\begin{array}{ll}- & \text { Environmental Sustainability Index } \\
- & \text { Dashboard of Sustainability } \\
- & \text { Wellbeing/Stress Index } \\
- & \text { Ecological footprint } \\
- & \text { Living Planet Index } \\
- & \text { Direct Material Consumption } \\
& \text { (DMC) }\end{array}$ \\
\hline $\begin{array}{l}\text { Gerbens-Leenes and } \\
\text { Nonhebel [32] }\end{array}$ & International & $\begin{array}{l}\text { Examine the association between } \\
\text { agricultural land use and eating patterns }\end{array}$ & $\begin{array}{l}\text { Eating patterns linked to greater wealth (i.e., cheese, } \\
\text { fruits and meats) require more agricultural lands. }\end{array}$ & Total per capita land requirements \\
\hline Risku-Norja et al. [33] & Finland & $\begin{array}{l}\text { Determine agricultural GHGE for } 4 \text { diet } \\
\text { settings and organic production in } \\
\text { comparison with industrial production }\end{array}$ & $\begin{array}{l}\text { Organic production has a higher GHGE because of } \\
\text { more cultivated acreage, and the main origin of } \\
\text { GHGEs from agricultural production is the soil } \\
\text { management practices. }\end{array}$ & Per capita GHGE (production only) \\
\hline
\end{tabular}


Table 1. Cont.

\begin{tabular}{|c|c|c|c|c|}
\hline Reference & Country & Objective of the Paper & Main Findings & Main Indicators/Index Identified \\
\hline Stehfest et al. [34] & International & $\begin{array}{l}\text { Measure the effect of a dietary shift toward } \\
\text { less meat on the environment }\end{array}$ & $\begin{array}{l}\text { The emissions of methane and nitrous oxide would } \\
\text { permit an increased carbon uptake, and consumption } \\
\text { of less meat would productively scale down land use. }\end{array}$ & $\begin{array}{l}\text { Integrated assessment } \\
\text { model framework }\end{array}$ \\
\hline Smedman et al. [14] & Sweden & $\begin{array}{l}\text { Evaluate GHGEs from producing } \\
\text { different beverages }\end{array}$ & $\begin{array}{l}\text { Milk has the highest GHGEs when compared to the } \\
\text { GHGEs of other beverages. }\end{array}$ & LCA \\
\hline Carvalho et al. [15] & Brazil & $\begin{array}{l}\text { Evaluate red-and processed-meat intake } \\
\text { and the impact meat consumption has on } \\
\text { diet attributes and the environment }\end{array}$ & $\begin{array}{l}\text { Diet quality was inversely associated with meat intake } \\
\text { in men. Meat consumption emitted greenhouse gas } \\
\text { emissions of } 18071988 \text { tonnes of } \mathrm{CO}_{2} \text { equivalents, } \\
\text { which represent about } 4 \% \text { of the total } \mathrm{CO}_{2} \text { emitted } \\
\text { by agriculture. }\end{array}$ & $\begin{array}{ll}- & \text { Brazilian Healthy Eating Index } \\
- & 24 \mathrm{~h} \text { dietary recall } \\
- & \text { Carbon footprint }\end{array}$ \\
\hline Macdiarmid et al. [35] & United Kingdom & $\begin{array}{l}\text { Determine the outcome of varied dietary } \\
\text { options on GHGEs }\end{array}$ & $\begin{array}{l}\text { The removal of meats and foods from dairy does not } \\
\text { necessarily lead to a reduction of diet-related GHGE. }\end{array}$ & LCA \\
\hline Scarborough et al. [36] & United Kingdom & $\begin{array}{l}\text { Models the effect of the three environmental } \\
\text { scenarios on life loss from cardiovascular } \\
\text { disease and cancer }\end{array}$ & $\begin{array}{l}\text { The model showed that in Scenario } 1 \text { resulted in } \\
36,910 \text { deaths prevented per year, and Scenario } 2 \\
\text { averted } 1999 \text { deaths per year, while Scenario } 3 \text { resulted } \\
\text { in } 9297 \text { deaths delayed per year. A } 19 \%, 9 \% \text { and } 3 \% \\
\text { reduction in GHGE characterised Scenarios 1, } 2 \\
\text { and } 3 \text { respectively. }\end{array}$ & LCA \\
\hline Capone et al. [37] & Italy & $\begin{array}{l}\text { Analysed the environmental cost of } \\
\text { nonadherence to the Mediterranean dietary } \\
\text { pattern from a water footprint perspective }\end{array}$ & $\begin{array}{l}\text { A reduced total water abstraction is linked to an } \\
\text { adherence to the Mediterranean dietary pattern. }\end{array}$ & Water footprint \\
\hline Liu and Zhang [38] & China & $\begin{array}{l}\text { Proposing a methodological framework for } \\
\text { measuring the sustainability level of main } \\
\text { agricultural regions in China on regional } \\
\text { and country levels }\end{array}$ & $\begin{array}{l}\text { The balanced method yields lower sustainable values } \\
\text { than the aggregate method and sensitivity analysis. }\end{array}$ & $\begin{array}{ll}- & \text { Land quality index } \\
- & \text { Resource carrying Index } \\
- & \text { Ecological risk index } \\
- & \text { Intensity of land management }\end{array}$ \\
\hline Masset et al. [39] & France & $\begin{array}{l}\text { Identify the most frequently consumed } \\
\text { sustainable diets by people daily }\end{array}$ & $\begin{array}{l}\text { The diets were categorized into lower carbon diets, } \\
\text { higher-quality diets and more-sustainable diets. Each } \\
\text { of them had beneficial outputs, but the } \\
\text { more-sustainable diets had the best outcome. }\end{array}$ & $\begin{array}{ll}- & \text { LCA } \\
- & \text { PANDiet score } \\
- & \text { Diet cost } \\
- & \text { Energy density } \\
\text { - } & \text { Energy content }\end{array}$ \\
\hline Masset et al. [40] & France & $\begin{array}{l}\text { Identify foods using measures of } \\
\text { sustainability dimensions }\end{array}$ & $\begin{array}{l}\text { Foods such as meat and fish had the biggest negative } \\
\text { impact on the environment. A low nutritional quality } \\
\text { and a high price characterised food that had a high } \\
\text { environmental impacts. }\end{array}$ & $\begin{array}{ll}- & \text { LCA } \\
- & \text { Freshwater eutrophication } \\
- & \text { Score for the nutritional adequacy } \\
\text { of individual foods (SAIN) } \\
\text { - } & \text { Score for disqualifying nutrients } \\
\text { (LIM) } \\
\text { - } & \text { 2006 KantatWorldPanel French } \\
\text { household consumer }\end{array}$ \\
\hline
\end{tabular}


Table 1. Cont.

\begin{tabular}{|c|c|c|c|c|}
\hline Reference & Country & Objective of the Paper & Main Findings & Main Indicators/Index Identified \\
\hline Peano et al. [41] & Italy & $\begin{array}{l}\text { To develop an indicator-based tool to } \\
\text { monitor sustainability in agric-food systems } \\
\text { using the Slow Food Presidia } \\
\text { project approach }\end{array}$ & $\begin{array}{l}\text { The Slow Food Presidia project increased all the } \\
\text { dimensions of sustainability and, in particular, } \\
\text { socioeconomic and cultural capital by preserving the } \\
\text { environmental quality aspects of the food products. }\end{array}$ & $\begin{array}{ll}- & \text { Ecosystem diversity } \\
- & \text { Species diversity } \\
- & \text { Genetic diversity } \\
- & \text { Water quality } \\
- & \text { Air quality } \\
- & \text { Erosion index }\end{array}$ \\
\hline Van Dooren et al. [42] & International & $\begin{array}{l}\text { Explore the relationship between } \\
\text { nutritionally healthy and ecologically } \\
\text { sustainable diets }\end{array}$ & $\begin{array}{l}\text { Meat and dairy consumption were mostly responsible } \\
\text { for low sustainability scores. }\end{array}$ & $\begin{array}{ll}- & \text { LCA } \\
- & \text { Land use }\end{array}$ \\
\hline $\begin{array}{l}\text { EAT Initiative, Sustainable } \\
\text { Development Solutions } \\
\text { Network (SDSN)and } \\
\text { Consultative Group for } \\
\text { International Agricultural } \\
\text { Research (CGIAR) [43] }\end{array}$ & International & $\begin{array}{l}\text { Develop integrated indicators for } \\
\text { Sustainable Food Systems and Healthy diets } \\
\text { in the Post-2015 Development Agenda }\end{array}$ & $\begin{array}{l}\text { Integrated indicators were developed in three } \\
\text { thematic categories: sufficient, nutritional, varied and } \\
\text { safe diets; climate-resilient and environmentally } \\
\text { sustainable food production; and resilient and } \\
\text { equitable food system. }\end{array}$ & 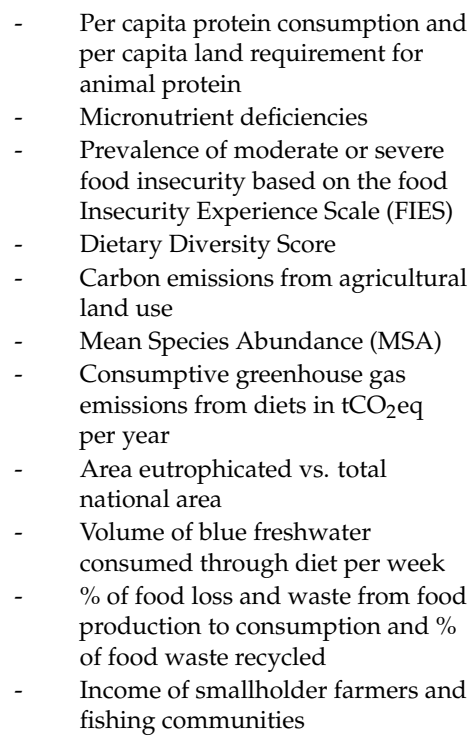 \\
\hline Gill et al. [44] & Brazil, China and India & $\begin{array}{l}\text { Evaluate the environmental effects of } \\
\text { dietary changes consistent with the } \\
\text { nutrition shifts }\end{array}$ & $\begin{array}{l}\text { Increases in cereal supply in China and India and beef } \\
\text { production in Brazil increased GHGEs and had an } \\
\text { effect on the phosphorus and nitrogen cycles, } \\
\text { respectively. }\end{array}$ & $\begin{array}{ll}\text { - } & \text { National availability indicators } \\
\text { Planetary boundaries } \\
\text { framework metrics }\end{array}$ \\
\hline
\end{tabular}


Table 1. Cont

\begin{tabular}{|c|c|c|c|c|}
\hline Reference & Country & Objective of the Paper & Main Findings & Main Indicators/Index Identified \\
\hline Ruini et al. [17] & Italy & $\begin{array}{l}\text { Present the Barilla centre for Food and } \\
\text { Nutrition's "Double Pyramid Model" in } \\
\text { order to raise people's awareness of the } \\
\text { impact of the environment on food }\end{array}$ & $\begin{array}{l}\text { A diet based on the principles of the Mediterranean } \\
\text { Diet (MD), as suggested by Double Pyramid, } \\
\text { generates a lower environmental impact compared to } \\
\text { diets that are heavily based on daily meat } \\
\text { consumption. Eating lower on the pyramid lowers the } \\
\text { environmental impact. }\end{array}$ & $\begin{array}{ll}- & \text { Carbon footprint } \\
- & \text { Water footprint } \\
- & \text { Ecological footprint }\end{array}$ \\
\hline Aleksandrowicz et al. [45] & International & $\begin{array}{l}\text { Review the evidence on changes on } \\
\text { sustainable dietary pattern in relation to } \\
\text { dietary intake on the environment variables }\end{array}$ & $\begin{array}{l}\text { An animal-based restriction was directly related to a } \\
\text { decrease in environmental footprints, and a dietary } \\
\text { transition yielded a moderate gain in the all-cause } \\
\text { mortality risk. }\end{array}$ & $\begin{array}{ll}- & \text { LCA } \\
- & \text { Land use } \\
- & \text { Water use }\end{array}$ \\
\hline Dernini et al. [8] & International & $\begin{array}{l}\text { Assessment of sustainability of diets based } \\
\text { on the MD }\end{array}$ & $\begin{array}{l}\text { A standard set of information (definition, } \\
\text { methodology, background, data sources, limitations of } \\
\text { the indicators and references) was provided for } \\
\text { thirteen nutrition indicators identified. }\end{array}$ & $\begin{array}{ll}\text { - } & \text { Food biodiversity composition } \\
\text { and consumption } \\
\text { - } & \text { Rate of local/regional foods } \\
\text { and seasonality } \\
\text { - } \quad \text { Rate of eco-friendly food } \\
\text { production and/or consumption } \\
\text { - } \quad \begin{array}{l}\text { Adherence to the Mediterranean } \\
\text { dietary pattern }\end{array}\end{array}$ \\
\hline Immacolata and Augusto [46] & Italy & $\begin{array}{l}\text { Measured environmental sustainability in } \\
\text { the food systems }\end{array}$ & $\begin{array}{l}\text { The application of the method of LCA for the } \\
\text { reduction of environmental shocks were related to the } \\
\text { life of the product chosen (olive oil), and the decisions } \\
\text { were related to interventions on processes, products } \\
\text { and activities. }\end{array}$ & - $\quad$ Life Cycle Assessment (LCA) \\
\hline Mertens et al. [47] & Netherlands & $\begin{array}{l}\text { To categorize and summarize the different } \\
\text { approaches to operationalise the health } \\
\text { aspects of environmentally sustainable diets }\end{array}$ & $\begin{array}{l}\text { Five approaches to operationalize the health aspects of } \\
\text { the diet were identified: food item replacement; } \\
\text { dietary guidelines; dietary quality scores; diet } \\
\text { modelling techniques; and a diet-related health } \\
\text { impact analysis. }\end{array}$ & $\begin{array}{ll}- & \text { LCA } \\
- & \text { Eco-indicator } \\
- & \text { Total ecological footprint } \\
- & \text { Land use } \\
- & \text { Energy efficiency } \\
- & \text { Water footprint }\end{array}$ \\
\hline Pires et al. [48] & International & $\begin{array}{l}\text { Evaluate how indicators related to water } \\
\text { use and management perform against a set } \\
\text { of sustainability criteria }\end{array}$ & $\begin{array}{l}\text { Twenty-four indicators comply with the majority of } \\
\text { the sustainability criteria; } 59 \text { indicators comply with } \\
\text { two sustainability criteria, while } 86 \text { indicators fulfill } \\
\text { just one of the four sustainability criteria; and one } \\
\text { indicator does not fulfil any of the } \\
\text { sustainability criteria. }\end{array}$ & $\begin{array}{ll}\text { - } & \text { Water footprint } \\
\text { - } & \text { Access to safe drinking water } \\
\text { - } & \text { Existence of legislation advocating } \\
& \text { for Dublin principles of water } \\
\text { - } & \text { Fresh water living planet index }\end{array}$ \\
\hline
\end{tabular}


Table 1. Cont.

\begin{tabular}{|c|c|c|c|c|}
\hline Reference & Country & Objective of the Paper & Main Findings & Main Indicators/Index Identified \\
\hline $\begin{array}{l}\text { Pellicer-Martinez and } \\
\text { Martinez [49] }\end{array}$ & Spain & $\begin{array}{l}\text { The use of a water footprint (WP) to assess } \\
\text { environmental sustainability in water } \\
\text { resources at the river basin level }\end{array}$ & $\begin{array}{l}\text { "Blue water" use is not sustainable due to a } \\
\text { generalized overexploitation of aquifers, and surface } \\
\text { water pollution is mainly caused by } \\
\text { phosphate concentration. }\end{array}$ & Water footprint \\
\hline Seconda et al. [50] & France & $\begin{array}{l}\text { Draw up a comparative description of four } \\
\text { diets differing in the level of organic food } \\
\text { consumption and the adherence to the } \\
\text { Mediterranean Diet (MD) using } \\
\text { multidisciplinary indicators to assess the } \\
\text { sustainability of these diets }\end{array}$ & $\begin{array}{l}\text { The adherence to nutritional recommendations was } \\
\text { highest among the organic consumers and } \\
\text { Mediterranean diet followers, lower among } \\
\text { conventional consumers and Mediterranean diet } \\
\text { followers and the lowest among conventional } \\
\text { consumers and non-Mediterranean diet followers. }\end{array}$ & $\begin{array}{ll}\text { - } & \text { Diet quality Index based on the } \\
\text { Probability of Adequate Nutrient } \\
\text { Intake PANDiet } \\
\text { - } & \text { Dietary Diversity Score } \\
\text { - } & \text { mPNNS-GS } \\
\text { - } & \text { Literature-based adherence score of } \\
\text { Mediterranean diet }\end{array}$ \\
\hline Dooren et al. [51] & Global & $\begin{array}{l}\text { Identify a set of important indicators to } \\
\text { assess the most pressing environmental } \\
\text { impacts of diets }\end{array}$ & $\begin{array}{l}\text { At the global and national levels, the planetary } \\
\text { boundaries and the footprint approaches were } \\
\text { respectively used to identify indicators, while the LCA } \\
\text { was used at the product (micro) level. }\end{array}$ & $\begin{array}{ll}- & \text { Climate impact } \\
- & \text { GHGE } \\
- & \text { Land use } \\
- & \text { Energy footprint } \\
- & \text { Water footprint } \\
- & \text { Carbon footprint } \\
- & \text { Ecological footprint }\end{array}$ \\
\hline Kramer et al. [18] & Netherlands & $\begin{array}{l}\text { Measure the performance of food products } \\
\text { in a sustainable diet based on the balance of } \\
\text { their contribution to nutrient intake and } \\
\text { environmental impact, within the context of } \\
\text { the Dutch diet }\end{array}$ & $\begin{array}{l}\text { Increasing amounts of dairy in the optimized diet } \\
\text { were associated with a steep increase in the } \\
\text { environmental impact and in meat. Bread and } \\
\text { breakfast cereals are sources of nutrients with a better } \\
\text { environmental performance compared to dairy or } \\
\text { meat within the context of the Dutch diet. }\end{array}$ & $\begin{array}{ll}- & \text { Carbon footprint } \\
- & \text { Nutrient balance metrics } \\
- & \text { GHGE } \\
- & \text { Fossil energy use } \\
- & \text { Land occupation }\end{array}$ \\
\hline Barre et al. [26] & France & $\begin{array}{l}\text { Assess the impact of nutrient bioavailability } \\
\text { and coproduction link considerations on } \\
\text { dietary changes needed to promote a } \\
\text { sustainable diet with a special focus on meat }\end{array}$ & $\begin{array}{l}\text { The "fruits and vegetables" and "starches" quantities } \\
\text { increased in all the modelled diets compared to the } \\
\text { mean observed French diet. }\end{array}$ & $\begin{array}{ll}\text { - } & \text { Bioavailability estimation } \\
\text { - } & \text { Nutrient calculation using food } \\
\text { - } & \text { composition databases } \\
- & \text { Atmo } \\
\text { - } & \text { Marine eutrophication } \\
\text { - } & \text { Diet cost analysis }\end{array}$ \\
\hline Osita et al. [52] & Japan & $\begin{array}{l}\text { Examined the impact of changes in a } \\
\text { Japanese diet from } 1961 \text { to } 2011 \text { and the } \\
\text { effect of alternative diets on the nitrogen } \\
\text { footprints of food }\end{array}$ & $\begin{array}{l}\text { The } 1975 \text { Japanese diet, a balanced omnivorous diet, } \\
\text { was reported to delay aging, with a protein content } \\
\text { similar to the current level, and to reduce the current } \\
\text { food nitrogen footprint }(15.2 \mathrm{~kg} \mathrm{~N}) \text { to } 12.6 \mathrm{~kg} \mathrm{~N} \text {, which } \\
\text { is comparable to the level in the protein diet } \\
(12.3 \mathrm{~kg} \mathrm{~N}) \text {. }\end{array}$ & Nitrogen footprint \\
\hline
\end{tabular}


Table 2. The nutrition and health indicators used for assessing a sustainable diet.

\begin{tabular}{|c|c|c|c|c|}
\hline Reference & & Objective of the Paper & Main Findings & Main Indicators/Index Identified \\
\hline Schacht et al. [53] & Norway & $\begin{array}{l}\text { Determine consumers' preference of fish with } \\
\text { different origins and management practices }\end{array}$ & $\begin{array}{l}\text { Farmed and wild salmon were least accepted while fish fed } \\
\text { with a feed of plant origin were more accepted compared to } \\
\text { other fishes. }\end{array}$ & - $\quad$ Sensory Evaluation Index \\
\hline Pearson [54] & Australia & $\begin{array}{l}\text { Determine the consumers' dietary preferences } \\
\text { in choosing organic foods }\end{array}$ & $\begin{array}{l}\text { Greater than half ( } 54 \% \text { ) of the respondents expressed } \\
\text { readiness to increase the organic consumption, and } 3 \% \text { of } \\
\text { them reported a high anticipation in the purchases of } \\
\text { organic foods. }\end{array}$ & $\begin{array}{l}\text { Analysis of online questionnaire of self-selected } \\
\text { adult food shoppers }\end{array}$ \\
\hline WHO [55] & International & $\begin{array}{l}\text { Measured health indicators of sustainable } \\
\text { agriculture, food and nutrition security }\end{array}$ & $\begin{array}{l}\text { The health indicators identified and linked to nutritional } \\
\text { status, food quality and trade policies and programmes. }\end{array}$ & $\begin{array}{l}\text { - Health outcome indicators such as } \\
\text { prevalence rates } \\
\text { Food access and dietary quality indicators which } \\
\text { include Household Dietary Diversity and the } \\
\text { prevalence/incidence of food borne } \\
\text { disease outbreaks } \\
\text { - } \quad \text { Food market/trade policies indicators }\end{array}$ \\
\hline Dixon and Isaacs [56] & Australia & $\begin{array}{l}\text { Assess consumer views on sustainable and } \\
\text { healthy diets }\end{array}$ & $\begin{array}{l}\text { Food purchase decisions were mainly influenced by cost, } \\
\text { availability and family responsibility and not necessarily by } \\
\text { sustainability or healthy foods. }\end{array}$ & $\begin{array}{ll}- & \text { Focus group results } \\
- & \text { Ethnography results }\end{array}$ \\
\hline Luckett et al. [57] & Malawi & $\begin{array}{l}\text { To estimate and examine the role of household } \\
\text { production and market acquisitions in } \\
\text { providing dietary diversity to farm households } \\
\text { in Malawi }\end{array}$ & $\begin{array}{l}\text { Households further from roads and population centres had } \\
\text { lower diversification }(p<0.01) \text { and spread through } \\
\text { comparatively more of their diversity from household } \\
\text { production than households closer to market centres } \\
(p<0.01) \text {. }\end{array}$ & Nutritional Functional Diversity Score \\
\hline Harry et al. [58] & Australia & $\begin{array}{l}\text { Assess the dietary assessment method of } \\
\text { sustainable dietary behaviour using a mobile } \\
\text { food record (mFR) application }\end{array}$ & $\begin{array}{l}\text { The use of mFR images for assessing fruit and vegetables, } \\
\text { eggs, red meat and poultry was developed and tested for } \\
\text { validity and reliability. }\end{array}$ & mobile food record (mFR) \\
\hline Benedetti et al. [59] & Italy & $\begin{array}{l}\text { Assess the current dietary patterns among } \\
\text { Italians, and analyse the effect of } \\
\text { socioeconomic and lifestyle factors on } \\
\text { Mediterranean diet constancy }\end{array}$ & $\begin{array}{l}\text { Of all the socioeconomic characteristics, education proved } \\
\text { to have a central role in determining the adherence to MD. } \\
\text { Individuals with at least } 8 \text { years of education increase from } \\
\text { the lowest }(39 \%) \text { to the highest ( } 44 \%) \text { category of the } \\
\text { Mediterranean score. }\end{array}$ & $\begin{array}{ll}\text { - } & \text { Food frequency questionnaire approach } \\
\text { - } & \text { Mediterranean Composite score }\end{array}$ \\
\hline Dernini et al. [60] & International & $\begin{array}{l}\text { Assessment of the sustainability of diets based } \\
\text { on the MD }\end{array}$ & $\begin{array}{l}\text { A standard set of information (definition, methodology, } \\
\text { background, data sources, limitations of the indicators and } \\
\text { references) was provided for thirteen nutrition } \\
\text { indicators identified. }\end{array}$ & $\begin{array}{ll}- & \text { Vegetable/animal protein consumption ratios } \\
\text { - } & \text { Average dietary energy adequacy } \\
\text { - } & \text { Dietary Energy Density Score } \\
\text { - } & \text { Nutrient density of diet } \\
\text { - } & \text { Food quality } \\
\text { - } & \text { Fruit and vegetable consumption/intakes } \\
\text { - } & \text { Dietary Diversity Score } \\
\text { - } & \text { Nutritional anthropidity/mortality statistics } \\
- & \text { Physical activity/physical inactivity prevalence }\end{array}$ \\
\hline
\end{tabular}


Table 2. Cont

\begin{tabular}{|c|c|c|c|c|}
\hline Reference & & Objective of the Paper & Main Findings & Main Indicators/Index Identified \\
\hline Benedetti et al. [61] & Italy & $\begin{array}{l}\text { Determine the current food patterns of Italians } \\
\text { using a composite indicator, and establish } \\
\text { which of the indicators had a higher adherence } \\
\text { to Mediterranean diet in Italy }\end{array}$ & $\begin{array}{l}\text { Education, the tendency to practice sports on a regular basis } \\
\text { and the ability to have breakfast and lunch at home } \\
\text { positively impact people's adherence to the } \\
\text { Mediterranean diet. }\end{array}$ & $\begin{array}{l}\text { Mediterranean Diet Index: frequencies of } \\
\text { consumption of } 14 \text { types of food (12 food groups } \\
\text { plus } 2 \text { types of oils and/or fats) }\end{array}$ \\
\hline Springmann et al. [16] & Global & $\begin{array}{l}\text { Examined three different approaches to } \\
\text { sustainable diets. }\end{array}$ & $\begin{array}{l}\text { Animal-source replacement with plant-based ones were } \\
\text { efficient, especially in improving nutrient levels, decreasing } \\
\text { untimely mortality and lowering the } \\
\text { environmental impacts. }\end{array}$ & $\begin{array}{l}\text { - } \quad \text { Nutrient content calculation } \\
\text { - } \quad \text { Replacement of } 25-100 \% \text { animal source foods } \\
\text { with plant-based ones at a constant total } \\
\text { calorie intake }\end{array}$ \\
\hline \multirow[t]{3}{*}{ Lachat et al. [62] } & Global & $\begin{array}{l}\text { Assessed the relationship between food } \\
\text { biodiversity and diet quality of women and } \\
\text { young children using diet species richness for } \\
\text { wet and dry seasons }\end{array}$ & $\begin{array}{l}\text { The dietary species richness showed stronger and more } \\
\text { consistent associations with the diet quality indicators } \\
\text { (Mean Adequacy Ratios and Dietary Diversity Scores) than } \\
\text { Simpson's index of Diversity index and } \\
\text { Functional Diversity. }\end{array}$ & $\begin{array}{l}\text { Simpson's index of diversity (represents number } \\
\text { of different species consumed) }\end{array}$ \\
\hline & & & & $\begin{array}{ll}\text { - } & \text { Functional diversity } \\
\text { - } & \text { Nutrient adequacy ratios }\end{array}$ \\
\hline & & & & $\begin{array}{ll}\text { - } & \text { Mean adequacy ratios } \\
\text { - } & \text { Dietary diversity Score } \\
\text { - } & \text { Minimum Dietary Diversity }\end{array}$ \\
\hline Vieux et al. [19] & Europe & $\begin{array}{l}\text { Determine if the dietary changes needed to } \\
\text { improve diet sustainability are similar across } \\
\text { some European countries }\end{array}$ & $\begin{array}{l}\text { Nutritional adequacy was not necessarily associated with a } \\
\text { reduced GHGE, and maximum GHGE reductions attainable } \\
\text { were filed from } 62 \text { to } 78 \% \text { with a minimal weight change of } \\
2.8 \mathrm{Kg} / \text { day from the observed diet. }\end{array}$ & $\begin{array}{ll}- & \text { GHGE } \\
- & \text { Diet weight } \\
- & \text { Energy weight } \\
- & \text { Mean absolute quantity variation of food items }\end{array}$ \\
\hline
\end{tabular}


Table 3. The socioeconomic indicators used for assessing a sustainable diet.

\begin{tabular}{|c|c|c|c|c|}
\hline Reference & & Objective of the Paper & Main Findings & Main Indicators/Index Identified \\
\hline $\begin{array}{l}\text { FAO (Food Agriculture } \\
\text { Organization) [63] }\end{array}$ & International & $\begin{array}{l}\text { Assess sustainability in the Food and } \\
\text { agriculture sector }\end{array}$ & $\begin{array}{l}\text { The sustainability monitoring and assessment routine } \\
\text { (SMART) was developed to be used by companies and the } \\
\text { agriculture sector. }\end{array}$ & $\begin{array}{ll}- & \text { Investment Index } \\
- & \text { Vulnerability Index } \\
- & \text { Product Quality and Information Index } \\
- & \text { Local Economy Index } \\
- & \text { Cultural diversity }\end{array}$ \\
\hline Jensen and Poulsen [64] & Denmark & $\begin{array}{l}\text { Assess the economic effects for the New } \\
\text { Nordic diet consumer compared with an } \\
\text { average Danish Diet }\end{array}$ & $\begin{array}{l}\text { The New Nordic Diet was about } 17 \% \text { more expensive than } \\
\text { the Average Danish Diet when the energy content of the } \\
\text { diet was adjusted and } 25 \% \text { more costly when there was } \\
\text { no adjustment. }\end{array}$ & Cost Index \\
\hline $\begin{array}{l}\text { Lombardini and } \\
\text { Lankoski [65] }\end{array}$ & Finland & $\begin{array}{l}\text { Assess the consequences of forced food choice } \\
\text { restriction in schools on students' diet }\end{array}$ & $\begin{array}{l}\text { The effects were manifested in a decrease in the number of } \\
\text { people who took part in school lunches and in the quantity } \\
\text { of food taken to the plate and in an increase in plate waste. }\end{array}$ & $\begin{array}{ll}- & \text { Food record } \\
- & \text { Lunch participation rate }\end{array}$ \\
\hline Peano et al. [41] & Italy & $\begin{array}{l}\text { Develop an indicator-based tool to monitor } \\
\text { sustainability in agric-food systems using the } \\
\text { Slow Food Presidia project approach }\end{array}$ & $\begin{array}{l}\text { The Slow Food Presidia project increased all dimensions of } \\
\text { sustainability and, in particular, socioeconomic and cultural } \\
\text { capital by preserving the environmental quality aspects of } \\
\text { the food products. }\end{array}$ & $\begin{array}{ll}- & \text { Supply chain } \\
\text { - } & \text { Price } \\
\text { - } & \text { Production Area Index }\end{array}$ \\
\hline Barosh et al. [66] & Australia & $\begin{array}{l}\text { Assess the affordability of a typical compared } \\
\text { to a healthy and sustainable food basket in } \\
\text { Greater Western Sydney, Australia }\end{array}$ & $\begin{array}{l}\text { Healthy and sustainable food basket was more costly than } \\
\text { the typical basket in all five socioeconomic } \\
\text { neighbourhoods studied. }\end{array}$ & $\begin{array}{l}\text { Price Index (price per unit weight of } \\
\text { food items) }\end{array}$ \\
\hline $\begin{array}{l}\text { IOM (Institute of Medicine) } \\
\text { and NRC (National } \\
\text { Research Council) [67] }\end{array}$ & USA & $\begin{array}{l}\text { Assess the social and economic effects of the } \\
\text { U.S. system }\end{array}$ & $\begin{array}{l}\text { Major classes of social and economic effects that can be } \\
\text { linked to characteristics of the U.S. food system } \\
\text { were outlined. }\end{array}$ & $\begin{array}{ll}\text { - } & \text { Income, Wealth and Equity Indices } \\
- & \text { Quality of life indicators } \\
- & \text { Food costs and expenditures indicators } \\
- & \text { Food security indices } \\
- & \text { Food quality indices }\end{array}$ \\
\hline Gustafson et al. [68] & USA & $\begin{array}{l}\text { Develop a methodology on the concept of } \\
\text { sustainable nutrition security using different } \\
\text { metrics }\end{array}$ & $\begin{array}{l}\text { Seven metrics for characterizing sustainable nutrition } \\
\text { outcomes of food systems were proposed and developed } \\
\text { using multiple indicators. }\end{array}$ & $\begin{array}{ll}- & \text { Gender equity } \\
\text { - } & \text { Extent of child labour } \\
\text { - } & \text { Respect for community rights } \\
\text { - } & \text { Animal health and welfare }\end{array}$ \\
\hline Barone et al. [69] & Brazil & $\begin{array}{l}\text { Investigating the association between } \\
\text { sustainability and foods, and to identify } \\
\text { consumer's perspective about the } \\
\text { characteristics of sustainable and } \\
\text { unsustainable foods }\end{array}$ & $\begin{array}{l}\text { The terms "healthy diet" and "sustainable production" } \\
\text { stood out in the sustainable diets concept. A higher } \\
\text { educational level of the participants linked food to the } \\
\text { natural environment and sustainability while individuals } \\
\text { with lower educational levels associated food with source, } \\
\text { nutrition and health. }\end{array}$ & $\begin{array}{l}\text { Questionnaire with word association, } \\
\text { free listing and sentence completion tasks }\end{array}$ \\
\hline
\end{tabular}


Table 4. The harmonized indicators for assessing sustainable food system.

\begin{tabular}{|c|c|c|}
\hline Nutrition and Health Indicators & Environment Indicators & Socio-Economic Indicators \\
\hline $\begin{array}{l}\text { - } \quad \text { Diet-related morbidity/mortality } \\
\text { Dietary Diversity/Nutrient } \\
\text { adequacy ratios } \\
\text { Nutritional } \\
\text { anthropometry/body composition } \\
\text { - } \quad \text { Physical activity/inactivity prevalence } \\
\text { Nutrients and Non-nutrient } \\
\text { assessment of some commonly } \\
\text { consumed foods }\end{array}$ & $\begin{array}{ll}\text { - } & \text { Ecological footprint } \\
\text { - } & \text { Carbon footprint } \\
\text { - } & \text { Water footprint } \\
\text { - } & \text { Rate of local/regional foods } \\
& \text { and seasonality } \\
\text { - } & \text { Environmental management } \\
\text { - } & \text { Fystem performance } \\
\text { Fuits and } \\
\text { - } & \text { Legetables biodiversity } \\
\text { Land use }\end{array}$ & $\begin{array}{l}\text { Income, wealth and } \\
\text { equity indicators }\end{array}$ \\
\hline
\end{tabular}

A tool of this type may be used in two ways: either retrospectively for a review and intercomparison of existing studies or prospectively as the basis for new research. In both cases, the use of a harmonized framework offers a solution to the problem of bridging methods and tools from research undertaken in varying settings.

The field-testing of the framework is recommended to identify any significant omissions or weaknesses. Thus, the limitation of the study was that some of the harmonized indicators have not been field-tested and that the review was limited to only studies that identified indicators that were specifically proposed or used. Further research is proposed to enhance the specificity of certain indicators, as well as to expand the purview of that harmonization efforts to include other methodological approaches.

Although the harmonised framework is intended for a wide application, the development of this tool was intended to investigate sustainable food systems among specific Pacific Island countries and Small Island Developing States. At the time of publication, the method has been deployed in the island state of Kiribati. Also, although the use of these harmonized indicators provides an overall impression of progress, it is not practicable or meaningful to combine all diverse indicator measures into a single index.

\section{Conclusions}

The review of the indicators for assessing sustainable food systems and sustainable diet reflects how much work has been done in measuring the environmental, nutritional/health and socioeconomic aspects of sustainable diet. Most of the indicators identified have been applied especially in the developed nations. Therefore, in the context of operationalizing these different aspects when designing sustainable diets, it is important to recognize that the concept of sustainable diets is not limited to food and nutrition but that it is used across multiple fields, which includes environment, agriculture, animal sciences, social and economic sciences. These harmonized indicators are principally intended to communicate and highlight progress in measuring a sustainable food system, to identify specific priority areas where action is required and to inform multi-sectoral policy development to achieve many of the Sustainable Development Goals.

Author Contributions: The coauthors had together contributed to the completion of this article. Specifically, their individual contribution are as follows: conceptualization, P.E.E. and B.B.; methodology, P.E.E., B.B., N.K., and J.D.; writing—original draft, P.E.E.; writing—review and editing, P.E.E., B.B., N.K., J.D., and S.F.

Funding: The research received no external funding.

Conflicts of Interest: The authors declared that they have no conflict of interest.

\section{References}

1. FAO/WHO/UNU. Human Energy Requirements. Report of a Joint FAO/WHO/UNU Expert Consultation; Food and Nutrition Technical Report Series; FAO: Rome, Italy, 2001. 
2. FAO. 31st Regional Conference for the Near East; Report; FAO Publications: Rome, Italy, 2012; pp. 14-17. Available online: www.fao.org/docrep/meeting/025/md988e.pdf (accessed on 12 December 2017).

3. Ericksen, P.J.; Bohle, H.G.; Stewart, B. Vulnerability and Resilience of Food Systems; Food Security and Global Environmental Change; Earthscan: London, UK; Washington, DC, USA, 2010; pp. 67-77.

4. Ingram, J.S.I.; Wright, H.L.; Foster, L.; Aldred, T.; Barling, D.; Benton, T.; Berryman, P.M.; Bestwick, C.S.; Bows-Larkin, A.; Brocklehurst, T.F.; et al. Priority research questions for the UK food system. Food Secur. 2013, 5, 617. [CrossRef]

5. HLPE. Food Losses and Waste in the Context of Sustainable Food Systems; High Level Panel of Experts on Food Security and Nutrition of the Committee on World Food Security: Rome, Italy, 2014.

6. FAO Fisheries and Aquaculture Department. The State of the World Fisheries and Aquaculture; Food and Agriculture Organization of the United Nations: Rome, Italy, 2009.

7. Bell, J.; Taylor, M. Building Climate-Resilient Food Systems for Pacific Islands; Program Report; WorldFish: Penang, Malaysia, 2015; p. 15.

8. Donini, L.M.; Dernini, S.; Lairon, D.; Serra-Majem, L.; Amiot, M.J.; del Balzo, V. A Consensus Proposal for Nutritional Indicators to Assess the Sustainability of a Healthy Diet: The Mediterranean Diet as a Case Study. Front. Nutr. 2016, 3, 37. [CrossRef] [PubMed]

9. UNIFEM. Strengthening of Gender Monitoring: Harmonization of Gender Indicators. 2006. Available online: www2.un.md/UNIFEM/programme_areas/statistics/harmonization/Best_Practices_ Development_process_of_gender_sensitive_indicators_in_Kyrgyzatan_eng.pdf (accessed on 2 March 2018).

10. Mulder, I.; Fahy, C.; Hribernik, K.; Velthausz, D.; Feurstein, K.; Garcia, M.; Schaffers, H.; Mirijamdotter, A.; Stahlbrost, A. Towards harmonized methods and tools for living labs. Conference Papers. PLoS ONE 2007, 11, e0165797. [CrossRef]

11. Mulder, I. Understanding Designers, Designing for Understanding; Telematica Instituut: Enschede, The Netherlands, 2004.

12. Jones, A.D.; Yosef, S. The implications of a changing climate on global nutrition security. In New Directions in the Fight against Hunger and Malnutrition; Sahn, D., Ed.; Oxford University Press: New York, NY, USA, 2015.

13. Carlsson-Kanyama, A. Climate change and dietary choices-How can emissions of greenhouse gases from food consumption be reduced? Food Policy 1998, 23, 277-293. [CrossRef]

14. Smedman, A.; Lindmark-Månsson, H.; Drewnowski, A.; Edman, A.K. Nutrient density of beverages in relation to climate impact. Food Nutr. Res. 2010, 54, 1-23. [CrossRef]

15. Carvalho, A.M.D.; Cesar, C.L.G.; Fisberg, R.M.; Marchioni, D.M. Excessive meat consumption in Brazil: Diet quality and environmental impacts. Public Health Nutr. 2013, 16, 1893-1899. [CrossRef]

16. Springmann, M.; Wiebe, K.; Mason-D'Croz, D.; Sulser, T.B.; Rayner, M.; Scarborough, P. Health and nutritional aspects of sustainable diet strategies and their association with environmental impacts: A global modelling analysis with country-level detail. Lancet Planet Health 2018, 2, e451-e461. [CrossRef]

17. Ruini, L.F.; Gati, R.; Pratesi, C.A.; Marino, M.; Principato, L.; Vannuzi, E. Working toward healthy and sustainable diets: The 'Double Pyramid Model' developed by the Barilla Centre for Food and Nutrition to raise awareness about the environmental and nutritional impact of foods. Front. Nutr. 2015, 2, 1-6. [CrossRef]

18. Kramer, G.F.H.; Martinez, E.V.; Espinoza-Orias, N.D.; Cooper, K.A.; Tyszler, M.; Blonk, H. Comparing the Performance of Bread and Breakfast Cereals, Dairy, and Meat in Nutritionally Balanced and Sustainable Diets. Front. Nutr. 2018, 5, 51. [CrossRef] [PubMed]

19. Vieux, F.; Perignon, M.; Gazan, R.; Darmon, N. Dietary changes needed to improve diet sustainability: Are they similar across Europe? Eur. J. Clin. Nutr. 2012, 72, 951-960. [CrossRef]

20. Hallstroem, E.; Carlsson-Kanyama, A.; BoÈrjesson, P. Environmental impact of dietary change: A systematic review. J. Clean. Prod. 2015, 91, 1-11. [CrossRef]

21. Joyce, A.; Hallett, J.; Hannelly, T.; Carey, G. The impact of nutritional choices on global warming and policy implications: Examining the link between dietary choices and greenhouse gas emissions. Energy Emiss. Control Technol. 2014, 2, 33-43. [CrossRef]

22. Villa, K.M.; Barrett, C.B.; Just, D.R. Whose Fast and Whose Feast? Intrahousehold Asymmetries in Dietary Diversity Response Among East African Pastoralists. Am. J. Agric. Econ. 2011, 93, 1062-1081. [CrossRef]

23. Karmakar, S.; Sarkar, D. Income inequality, poverty and food security in West Bengal, India. J. Soc. Sci. Stud. 2014, 1, 31-43. [CrossRef] 
24. The Sustainability Consortium. Transforming the Consumer Goods Industry to Deliver More Sustainable Consumer Products; The Sustainability Consortium: Fayetteville, AR, USA, 2015.

25. Azzini, E.; Durazzo, A.; Polito, A.; Veneria, E.; Foddai, M.S.; Zaccaria, M.; Mauro, B.; Intorre, F.; Maiani, G. Biodiversity and local food products in Italy. In Sustainable Diets and Bioversity: Directions and Solutions for Policy, Research and Action-Chapter 4; FAO and Bioversity International: Roma, Italy, 2015.

26. Barré, T.; Perignon, M.; Gazan, R.; Vieux, F.; Micard, V.; Amiot, M.-J. Integrating nutrient bioavailability and co-production links when identifying sustainable diets: How low should we reduce meat consumption? PLoS ONE 2018, 13, e0191767. [CrossRef]

27. Wratten, S.D.; Hofmans, M.; Thomsen, S.; Williams, P.; Groves, G.; Eason, C. Measuring Sustainability in agricultural systems. In Proceedings of the 50th New Zealand Plant Protection Conference, Lincoln, New Zealand, 18-21 August 1997; pp. 514-519.

28. Jungbluth, N.; Tietje, O.; Scholz, R. Food purchases: Impacts from the consumers' point of view investigated with a modular LCA. Int. J. Life Cycle Assess. 2000, 5, 134-142. [CrossRef]

29. White, T. Diet and the distribution of environmental impact. Ecol. Econ. 2000, 34, 145-153. [CrossRef]

30. Gerbens-Leenes, P.W.; Moll, H.C.; SchootUiterkamp, A.J.M. Design and development of a measuring method for environmental sustainability in food production systems. Ecol. Econ. 2003, 46, 231-245. [CrossRef]

31. Moldan, B.; Hak, T.; Knvanda, J.; Havranek, M.; Kuskora, P. Composite indicators of environmental sustainability. In Proceedings of the Statistics, Knowledge and Policy, OECD World Forum on Key Indicators, Palermo, Italy, 10-13 November 2004.

32. Gerbens-Leenes, W.; Nonhebel, S. Food and land use. The influence of consumption patterns on the use of agricultural resources. Appetite 2005, 45, 24-31. [CrossRef]

33. Risku-Norja, H.; Kurppa, S.; Helenius, J. Dietary choices and greenhouse gas emissions-Assessment of impact of vegetarian and organic options at national scale. Programme Ind. Econ. 2009, 6, 340-354. [CrossRef]

34. Stehfest, E.; Bouwman, L.; van Vuuren, D.; den Elzen, M.J.; Eickhout, B.; Kabat, P. Climate benefits of changing diet. Clim. Chang. 2009, 95, 83-102. [CrossRef]

35. MacDiarmid, J.I.; Kyle, J.; Horgan, G.W.; Loe, J.; Fyfe, C.; Johnstone, A.; McNeill, G. Sustainable diets for the future: Can we contribute to reducing greenhouse gas emissions by eating a healthy diet? Am. J. Clin. Nutr. 2012, 96, 632-639. [CrossRef]

36. Scarborough, P.; Allender, S.; Clarke, D.; Wickramasinghe, K.; Rayner, M. Modelling the health impact of environmentally sustainable dietary scenarios in the UK. Eur. J. Clin. Nutr. 2012, 66, 710-715. [CrossRef]

37. Capone, R.; Iannetta, M.; El Bilali, H.; Nicola, C.; Debs, P.; Dernini, S.; Maiani, G.; Intorre, F.; Polito, A.; Turrini, A.; et al. A Preliminary Assessment of the Environmental Sustainability of the Current Italian Dietary Pattern: Water Footprint Related to Food Consumption. J. Food Nutr. Res. 2003, 1, 59-67.

38. Liu, F.; Zhang, H. Novel methods to assess environmental, economic and social sustainability of main agricultural regions in China. Agrob. Sustain. Dev. 2013, 33, 621-633. [CrossRef]

39. Masset, G.; Soler, L.G.; Vieux, F.; Darmon, N. Identifying sustainable foods: The relationship between environmental impact, nutritional quality and prices of foods representative of the French diet. J. Acad. Nutr. 2014, 114, 862-869. [CrossRef]

40. Masset, G.; Vieux, F.; Verger, E.O.; Soler, L.G.; Touazi, D.; Darmon, N. Reducing energy intake and energy density for a sustainable diet: A study based on self-selected diets in French adults. Am. J. Clin. Nutr. 2014, 99, 1460-1469. [CrossRef]

41. Peano, C.; Migliorini, P.; Sottile, F. A methodology for the sustainability assessment of agri-food systems: An application to the Slow Food Presidia project. Ecol. Soc. 2014, 19, 24. [CrossRef]

42. Van Dooren, C.; Marinussen, M.; Blonk, H.; Aiking, H.; Vellinga, P. Exploring dietary guideline based on ecological and nutritional values: A comparison of six dietary patterns. Food Policy 2014, 44, 36-46. [CrossRef]

43. EAT, SDDSN and CGIAR. Integrated Indicators for Sustainable Food Systems and Healthy Diets in the Post-2015 Development Agenda. Final Statement Prepared by the Working Group-A Partnership between EAT, SDDSN and CGIAR. 2015. Available online: https:/ / ggspace.cgiar.org/handle/10947/4011 (accessed on 2 April 2019).

44. Gill, M.; Feliciano, D.; Macdiarmid, J.; Smith, P. The environmental impact of nutrition transition in three case study countries. Food Secur. 2015, 7, 493-504. [CrossRef] 
45. Aleksandrowicz, L.; Green, R.; Joy, E.J.M.; Smith, P.; Haines, A. The Impacts of Dietary Change on Greenhouse Gas Emissions, Land Use, Water Use, and Health: A Systematic Review. PLoS ONE 2016, 11, e0165797. [CrossRef] [PubMed]

46. Immacolata, V.; Augusto, M. Life Cycle Assessment and environmental sustainability in the food system. Agric. Agric. Sci. Procedia 2016, 8, 317-323.

47. Mertens, E.; Veer, P.V.; Hiddink, G.J.; Steijns, J.; Kuijsten, A. Operationalising the health aspects of sustainable diets: A review. Public Health Nutr. 2016, 20, 739-757. [CrossRef]

48. Pires, A.; Morato, J.; Peixoto, H.; Botero, V.; Zuluaga, L.; Figuero, A. Sustainability Assessment of indicators for integrated water resources management. Sci. Total Environ. 2017, 578, 139-147. [CrossRef]

49. Pellicer-Martínez, F.; Martínez-Paz, J.M. Grey water footprint assessment at the river basin level: Accounting method and case study in the Segura River Basin, Spain. Ecol. Indices 2016, 60, 1173-1183. [CrossRef]

50. Seconda, L.; Baudry, J.; Allès, B.; Hamza, O.; Boizot-Szantai, C.; Soler, L.-G.; Galan, P.; Hercberg, S.; Lairon, D.; Kesse-Guyot, E. Assessment of the sustainability of the Mediterranean Diet combined with organic food consumption: An individual Behaviour Approach. Nutrients 2017, 9, 61. [CrossRef] [PubMed]

51. Dooren, C.V.; Aiking, H.; Vellinga, P. In search of indicators to assess the environmental impact of diets. Int. J. Life Cycle Asses. 2018, 23, 1297-1314. [CrossRef]

52. Osita, A.; Nagano, I.; Matsuda, H. Food Nitrogen footprint reductions related to a balanced Japanese diet. Ambio 2018, 47, 318-326.

53. Schacht, K.; Filho, W.L.; Koppe, W.; Struksnaes, G.; Busch-Stockfisch, M. Sustainability as a new paradigm regarding food consumption. Br. Food J. 2010, 112, 476-488. [CrossRef]

54. Pearson, D.; Bailey, A. Exploring the Market Potential of 'Local' in Food Systems. Locale Australas. Pac. J. Reg. Food Stud. 2012, 2, 82-103.

55. WHO. Health Indicators of Sustainable Agriculture, Food and Nutrition Security in the Context of the RIO +20 UN Conference on Sustainable Development; Initial Findings from a WHO Expert Consultation from 17-18 May 2012; WHO: Geneva, Switzerland, 2012.

56. Dixon, J.; Isaacs, B. Why sustainable and 'nutritionally correct' food is not on the agenda: Western Sydney, the moral arts of everyday life and public policy. Food Policy 2013, 43, 67-76. [CrossRef]

57. Luckett, B.G.; Declerck, F.A.J.; Fanzo, J.; Mundorf, A.R.; Rose, D. Application of the Nutrition Functional Diversity Indicator to assess food system contributions to dietary diversity and sustainable diets of Malawian Households. Public Health Nutr. 2015, 18, 2479-2487. [CrossRef]

58. Harry, A.J.; Boushey, C.J.; Pollard, C.M.; Delp, E.J.; Ahmad, Z.; Dhaliwal, S.S.; Mukhtar, S.; Kerr, D. Novel Dietary assessment method to measure a healthy and sustainable diet using the mobile food record: Protocol and methodology. Nutrients 2015, 7, 5375-5395. [CrossRef]

59. Benedetti, I.; Biggeri, L.; Laureti, T.; Secondi, L. Exploring the Italians' food habits and tendency towards a sustainable diet: The Mediterranean eating pattern. Agric. Agric. Sci. Procedia 2016, 8, 433-440. [CrossRef]

60. Dernini, S.; Meybeck, A.; Burlingame, B.; Gitz, G.; Lacirignola, C.; Debs, P.; Capone, R.; El Bilali, H. Developing a methodological approach for assessing the sustainability of diets: The Mediterranean diet as a case study. New Medit 2013, 12, 28-36.

61. Benedetti, I.; Laureti, T.; Secondi, L. Choosing a healthy and sustainable diet: A three-level approach for understanding the drivers of the Italians' dietary regime over time. Appetite 2018, 123, 357-366. [CrossRef] [PubMed]

62. Lachat, C.; Raneri, J.E.; Smith, K.W.; Kolsteren, P.; Damme, P.V.; Penafiel, D.; Penafiel, D.; Vanhove, W.; Kennedy, G.; Hunter, D.; et al. Dietary species richness as a measure of food biodiversity and nutritional quality of diets. Proc. Natl. Acad. Sci. USA 2018, 115, 127-132. [CrossRef]

63. FAO. Nutrition Indicators for Development; FAO Publications: Rome, Italy, 2003.

64. Jensen, J.D.; Poulsen, S.K. The new nordic diet-Consumer expenditures and economic incentives estimated from a controlled intervention. BMC Public Health 2013, 13, 1-9. [CrossRef]

65. Lombardini, C.; Lankoski, L. Forced choice restriction in promoting sustainable food consumption: Intended and unintended effects of the mandatory vegetarian day in Helsinki Schools. J. Consum. Policy 2013, 36, 159-178. [CrossRef]

66. Barosh, L.; Friel, S.; Engelhardt, K.; Chan, L. The cost of a healthy and sustainable diet—Who can afford it? Aust. N. Z. J. Public Health 2014, 38, 7-12. [CrossRef] [PubMed] 
67. Institute of Medicine (IOM) and National Research Council (NRC). A Framework for Assessing Effects of the Food System; The National Academies Press: Washington, DC, USA, 2015.

68. Gustafson, D.; Gutman, A.; Leet, W.; Drewnowski, A.; Fanzo, J.; Ingram, J. Seven Food System metrics of Sustainable Nutrition Security. Sustainablity 2016, 8, 196. [CrossRef]

69. Barone, B.; Nogueira, R.M.; Guimaraes, K.R.L.; Behrens, J.H. Sustainable diet from the urban Brazilian consumer perspective. Food Res. Int. 2018. [CrossRef]

(C) 2019 by the authors. Licensee MDPI, Basel, Switzerland. This article is an open access article distributed under the terms and conditions of the Creative Commons Attribution (CC BY) license (http:// creativecommons.org/licenses/by/4.0/). 